\title{
Pergeseran Nilai Ritual Kaghombo dalam Tradisi Masyarakat Muna
}

\author{
La Tarifu ${ }^{1}$, La Ode Herman Halika ${ }^{2}$ \\ ${ }^{12}$ Universitas Halu Oleo - Kendari \\ Jl. Anduonou, Kambu, Kendari - Sulawesi Tenggara 93132 \\ 2herman_khalik@yahoo.com
}

\begin{abstract}
This research discusses the shifting of Kaghombo ritual value as symbolic interaction meaning in Muna society seen from aspect of culture and intercultural communication. The Kaghombo Ritual is one of the rituals of the Muna community that is performed as the peak of kangkilo (sunatan) of the girls, and has noble values that can be applied in the daily life of the Muna community, especially in Mabolu Village. The values in this ritual are very important for the life of the Muna community because it contains social, religious, philosophical and historical aspects. Kaghombo's ritual changes in its development are influenced by various internal and external aspects of the change of its supporting society. Internal factors include trust, religion, and development of Education, while external factors include economic aspects. As for the results of research: Mabolu Village community thought especially kalambe wuna (girl dipingit) began to be influenced by new things gained from modern education. This thinking assumes in some parts of the ritual, its stages contrary to modern thought. For example, that this ritual is performed as a process of maturation and self-purification in the face of everyday life and domestic life.
\end{abstract}

Keywords: Cultural Values, Kaghombo Rituals, Cultural Traditions, Intercultural Communication

\begin{abstract}
Abstrak
Penelitian ini membahas pergeseran nilai ritual Kaghombo sebagai makna interaksi simbolik dalam masyarakat Muna dilihat dari segi aspek budaya dan komunikasi antarbudaya. Ritual Kaghombo merupakan salah satu ritual masyarakat Muna yang dilaksanakan sebagai puncak kangkilo (sunatan) dari anak perempuan, dan memiliki nilai-nilai luhur yang dapat diterapkan dalam kehidupan sehari-hari masyarakat Muna khususnya di Desa Mabolu. Nilai-nilai dalam ritual ini sangat penting bagi kehidupan masyarakat Muna karena memuat aspek sosial, religius, filosofis dan kesejarahan. Perubahan ritual Kaghombo dalam perkembangannya dipengaruhi oleh berbagai aspek internal dan eksternal perubahan masyarakat pendukungnya. Faktor internal meliputi kepercayaan, agama, dan perkembangan Pendidikan, sedangkan faktor eksternal antara lain aspek ekonomi. Adapun hasil penelitian: pemikiran masyarakat Desa Mabolu khususnya kalambe wuna (gadis yang dipingit) mulai terpengaruh dengan hal-hal baru yang didapat dari pendidikan modern. Pemikiran ini menganggap pada beberapa bagian ritual, tahapannya bertentangan dengan pemikiran modern. Misalnya, bahwa ritual ini dilakukan sebagai proses pematangan dan pensucian diri dalam menghadapi kehidupan sehari-hari dan kehidupan rumah tangga.
\end{abstract}

Kata kunci: Nilai budaya, Ritual Kaghombo, Tradisi budaya, Komunikasi antarbudaya

Copyright @ 2018 Ikatan Sarjana Komunikasi Indonesia. All rights reserved

\section{PENDAHULUAN}

Dewasa ini pola kehidupan sosial budaya sehari-hari masyarakat Muna telah menunjukkan berbagai pengaruh yang sangat kuat, yang disebut sebagai pola kehidupan global. Warga masyarakat mengalami berbagai perubahan cara hidup, gaya hidup, bahkan pandangan hidup mereka. Maka, perubahan tersebut telah mengancam keberadaan ritual lokal, antara lain warisan budaya, kebiasaan, nilai, identitas, dan simbol-simbol kehidupan masyarakatnya (Giddens 2003: 915). Perubahan tersebut dapat dilihat dengan berubahnya waktu pelaksanaan ritual Kaghombo, 
proses pelaksanaan, serta alat-alat yang digunakan dalam ritual tersebut. Ritual Kaghombo dilaksanakan oleh masyarakat Muna, baik yang tetap berada di daerah Muna maupun yang sudah pindah ke daerah lain. Menurut cerita, ritual Kaghombo pertama kali diadakan selama 40 hari 40 malam oleh Raja Muna XVI (1716-1757) yaitu La Ode Huseini (Omputo Sangia). Namun, pelaksanaan ritual Kaghombo sekarang tidak lagi seperti yang diadakan oleh raja Muna tetapi menjadi empat hari empat malam. Ritual ini berkembang dalam masyarakat Muna sebagai ritual "pelunasan" tanggung jawab orang tua terhadap anak perempuannya. Mereka akan merasa berdosa bila menikahkan anaknya tanpa menjalankan ritual Kaghombo. Ritual ini juga dianggap sebagai pembekalan nilai-nilai etika, moral, dan spritual terhadap anak perempuan agar kelak dalam mengarungi bahtera rumah tangga, ataupun dalam kehidupan bermasyarakat dapat mengerti dan menempatkan diri dengan baik sebagai seorang perempuan yang dimuliakan kedudukannya. Hal ini mempertegas status kalambe wuna sebagai perempuan yang patut dihargai dan dituntut mampu menjaga kehormatan keluarga (Couvreur, 2001:1-4).

Ritual Kaghombo ini menjadi bagian dari kehidupan masyarakat Muna yang memiliki adatistiadat dalam setiap menjalani siklus kehidupan. Pewarisan ritual ini didapatkan secara langsung dari keturunan keluarga. Proses pewarisan yang terjadi di dalam masyarakat pendukung ritual ini, meliputi segala hal yang berhubungan dengan proses pelaksanaan, penentuan waktu maupun yang berhubungan dengan tata cara pelaksanaannya. Mantra atau bhatata yang digunakan dalam ritual ini juga diwariskan dari pembawa ritual. Hal ini menggambarkan ritual Kaghombo merupakan milik kolektif masyarakat Muna. Dalam kehidupan sehari-hari masyarakat Muna juga menghargai ritual dan kebudayaan etnis lain, tetapi dalam interaksi tertentu tetap berperilaku dan hidup menurut budaya mereka sendiri.

Masyarakat Muna memahami ritual ini sebagai puncak dari ritual yang harus dilakukan kaum perempuan sebelum memasuki pernikahan. Pada setiap ritual masyarakat Muna dipahami sebagai rangkaian atau proses adat atau tata cara yang berlaku dalam masyarakat yang berhubungan dengan berbagai kejadian dalam masyarakat pendukungnya. Begitupun halnya dengan ritual Kaghombo, dianggap sebagai doa dan dipercaya dapat membersihkan jiwa dan raga kaum perempuan dari hal-hal yang buruk selama hidupnya.

Ritual Kaghombo mempunyai peranan dan kedudukan penting dalam kehidupan masyarakat Muna. Ritual ini merupakan siklus hidup perempuan Muna yang dilakukan sebagai tutura (pencerahan). Tutura Kaghombo dapat memperlihatkan kematangan diri perempuan dalam menghadapi kehidupan secara khusus dalam berumah tangga dan pembauran dalam masyarakat secara umum.

Ritual Kaghombo menjadi simbol proses terciptanya manusia dari setetes darah hingga menjadi manusia sempurna. Hal ini mempertegas ritual Kaghombo memuat falsafah hidup bagi masyarakat Muna yang senantiasa membimbing masyarakat Muna untuk bersikap baik, saling menghargai, menghormati orang yang lebih tua dan mengutamakan kebersamaan masyarakat Muna.

Selain itu juga dapat dikatakan bahwa ritual Kaghombo merupakan ekspresi dan interaksi simbolik dalam masyarakat Muna, khususnya bagi masyarakat Muna Desa Mabolu yang memiliki anak perempuan. Hal ini disebabkan ritual tersebut juga memuat pandangan hidup dan sistem kepercayaan.

Dari latar belakang di atas dapat dikemukakan dua masalah yang berkaitan dengan ritual Kaghombo sebagai makna interaksi simbolik dan hubungannya dengan pelestarian dan 
pengembangan ritual pada masyarakat Muna, yaitu: Bagaimaana pergeseran nilai ritual Kaghombo (Pingitan) sebagai Tradisi Budaya Masyarakat Muna.

\section{KERANGKA TEORITIS}

Ritual merupakan sarana yang menghubungkan manusia dengan hal-hal yang dianggap sakral. Ritual dipahami sebagai bentuk penyelenggaraan hubungan antara manusia kepada yang gaib, hubungan manusia dengan sesamanya, dan hubungan manusia pada lingkungannya. Untuk itu ritual bukan hanya dianggap sebagai sarana yang memperkuat ikatan sosial kelompok, tetapi sebagai cara perayaan peristiwa-peristiwa penting dalam kehidupan masyarakat.

Ritual merupakan kebiasaan yang dilakukan oleh sebagian besar masyarakat dalam siklus kehidupan sejak zaman dahulu. Dalam proses pelaksanaannya ritual tidak terlepas dari penggunaan bahasa dan kata-kata sebagai media penyampaiannya. Bahasa dan kata-kata yang sering digunakan dalam ritual disebut mantra. Ritual adalah sarana yang menghubungkan manusia dengan hal-hal yang dianggap sakral. Ritual merupakan bagian dari proses pelaksanaannya Kaghombo yang tidak terlepas dari penggunaan bahasa dan kata-kata sebagai media penyampaiannya. Ritual dikelompokkan menjadi dua bagian yaitu ritual krisis hidup, dan ritual gangguan. Ritual krisis hidup artinya ritual yang berhubungan dengan hidup manusia dimana seseorang akan masuk dalam lingkup perubahan tahap hidup seperti kelahiran, pubertas dan kematian. Sedangkan ritual gangguan yaitu ritual sebagai negosiasi dengan roh halus agar tidak mengganggu manusia. Dalam ritual ini perempuan diajarkan agar selalu siap menghadapi segala hal yang akan terjadi dalam kehidupan sehari-hari atau dalam rumah tangganya.

Ritual Kaghombo merupakan ritual adat masyarakat Muna, pertama kali diadakan pada masa pemerintahan Raja Muna XVI, La Ode Huseini yang bergelar Omputo Sangia terhadap putrinya, Wa Ode Kamomono Kamba (La Oba, dkk. 2008:4). Setelah proses Kaghombo selesai, perempuan diyakini bagaikan kertas putih, dan memahami seluk beluk kehidupan duniawi khususnya kehidupan berumah tangga menuju pada pembentukan keluarga sakinah, mawaddah dan warahmah. Ritual Kaghombo sebagai salah satu bagian dari budaya masyarakat Muna yang tidak pernah berdiri sendiri tanpa masyarakat pendukungnya.

Menurut Kayam (1981:38-39), masyarakat adalah faktor penting dalam menyangga kebudayaan, mencipta, memberi kebebasan bergerak, memelihara, mengembangkan untuk menciptakan kebudayaan baru. Budaya berarti kebiasaan dan ritual yang mengatur dan menetukan hubungan sosial kita berdasarkan kehidupan sehari-hari sebagaimana halnya dengan teks-teks tersebut-sastra, musik, televisi, dan film-dan melalui kebiasaan serta ritual tersebut dunia sosial dan natural ditampilkan kembali atau ditandai-dimaknai-dengan cara tertentu yang sesuai dengan konvensi tertentu (Barker. 1980: 28-30).

Menurut Soemardjan dan Soemardi (dalam Soekanto, 2007), budaya adalah semua hasil karya, cipta dan rasa dalam masyarakat. Karya masyarakat akan menghasilkan teknologi dan kebudayaan kebendaan atau kebudayaan jasmaniah (biasa disebut material culture) yang diperlukan oleh manusia untuk menguasai alam sekitarnya agar kekuatan serta hasilnya dapat diabdikan untuk keperluan masyarakat.

Menurut Liliweri (2004), komunikasi antarbudaya adalah setiap proses pembagian informasi, gagasan atau perasaan diantara mereka yang berbeda latar belakang budayanya. Proses pembagian informasi itu dilakukan secara lisan dan tertulis, juga melalui bahasa tubuh, gaya atau penampilan pribadi, atau bantuan hal lain di sekitarnya yang memperjelas pesan. 
Komunikasi antarbudaya lebih cenderung dikenal sebagai perbedaan budaya dalam mempersepsi obyek-obyek sosial dan kejadian-kejadian, di mana masalah-masalah kecil dalam Komunikasi sering diperumit oleh adanya perbedaan-perbedaan persepsi dalam memandang masalah itu sendiri. Dalam hal ini komunikasi antarbudaya diharapkan berperan memperbanyak dan memperdalam persamaan dalam persepsi dan pengalaman seseorang.

\section{METODE PENELITIAN}

Penelitian dilakukan di Desa Mabolu, Kecamatan Lohia, Kabupaten Muna, Propinsi Sulawesi Tenggara dengan pertimbangan di Desa itu masih melaksanakan ritual Kaghombo, masih ada pomantoto, dan masyarakatnya masih meyakini ritual Kaghombo tetap berfungsi dalam kehidupan mereka, meskipun tahapan pelaksanaannya tidak lagi menjadi sakral. Artinya, ritual haghombo hanya dianggap sebagai aturan yang harus dilaksanakan orang tua terhadap anaknya. Generasi muda yang sudah terpengaruh dengan kemajuan informasi dan teknologi serta perkembangan zaman, tidak lagi mengetahui nilai-nilai dalam ritual yang menjadi bagian dari siklus kehidupan masyarakat Muna.

Informan yang dipilih adalah para tokoh adat/agama, tokoh masyarakat dan pomantoto sebanyak enam orang yang ditemukan secara sengaja (purposive sampling), dengan pertimbangan mereka dapat memberikan keterangan terkait ritual Kaghombo, mengacu pada Spradley dalam Endraswara (2003:207) yang menjelaskan, informan yang baik adalah mereka yang terlibat langsung dalam kebudayaan yang memiliki waktu dan wawancara.

Teknik penentuan informan menggunakan purposive sampling. Penentuan informan ini berdasarkan populasi yang sesuai dengan karakteristik penelitian yaitu dengan sengaja memilih informan yang dianggap kapabel dan mampu memberikan informasi yang sesuai dengan kajian penelitian. Untuk mengumpulkan data-data dilakukan dengan cara penelitian langsung di lapangan untuk memperoleh data dan informasi dengan cara (1) pengamatan, (2) wawancara, dan (3) studi pustaka.

\section{HASIL PENELITIAN}

Pelaksanaan kegiatan inti ritual Kaghombo terletak pada proses penempaan para gadis untuk melewati empat alam: (1) alam arwah, (2) alam misal, (3) alam aj"sam dan (4) alam insane. Proses pemindahan dari satu alam ke alam yang lain hingga manusia dilahirkan bagai kertas putih polos dan suci, dapat digambarkan dari tahapan pelaksanaan: (1) Kafoluku (Pemasukan); (2) Kabhansule (Perubahan Posisi); (3) Kalempangi (Pembukaan); (4) Kafosampu (Pemindahan); (5) Katandano Wite (Penyentuhan Tanah; (6) Tari Linda, (7) Kaghorono Bhansa (Penyelaman Mayang Pinang).

Telah dikatakan sebelumnya bahwa ada unsur-unsur ritual ini yang tetap bertahan. Namun, seiring dengan perkembangan zaman sebagian tahapan dalam pelaksanaan ritual Kaghombo tidak dilaksanakan sesuai dengan ketentuan adat yang sebenarnya.

Waode Faaliha mengatakan proses tahapan pelaksanaan ritual Kaghombo saat ini mengalami pergeseran nilai dan fungsi, sebagai pomantoto merasakan banyak hal yang berbeda pelaksanaan ritual ini.

“...ada banyak yang berbeda dalam tahapan pelaksanaan dan perlengkapan yang digunakan dalam ritual ini. Waktu saya di Kaghombo, semua tahapannya dilaksanakan dan perlengkapannya pun tidak dikurangi atau dihilangkan. Sekarang ini tombula untuk 
pengambilan air, bhosu (termos) untuk menyimpanan air, kamba wuna, padjamara sudah hampir tidak digunakan. Begitupula dengan tahapan pelaksanaan. Misalnya malam ketiga alono kamboto (malam begadang) tidak ada lagi yang namanya kafolego, tari pogala, pengambilan patirangka dan nyanyian sare. Semua tahapan ini sebagian besar ketika saya jadi pomantoto tidak dilaksanakan oleh masyarakat pendukung ritual ini..."(Wawancara dengan Waode Faaliha, Senin, 11 September 2016).

Pada tahapan kafoluku (proses selama dalam tempat Kaghombo), kabhansule (perubahan posisi) dan tari linda, tidak dilaksanakan sesuai dengan ketentuan yang telah disepakati secara turun-temurun. Hal ini didapatkan penulis, ketika menyaksikan proses pelaksanaan ritual ini. Pada tahap kafoluku yang seharusnya pada malam ketiga atau lebih dikenal dengan alono kamboto (malam bergadang) diisi dengan kegiatan pembacaan doa, pengambilan patirangka (imam membaca takbir), tari pogala dan tari linda yang diringi nyanyian sare yang dilakukan masyarakat di luar tempat pemingitan. Kenyataanya, ritual alono kamboto ini sebagian besar tidak lagi dilakukan. Pelaksana ritual hanya mengisi malam ketiga dengan persiapan pembuatan panggung dan pemukulan ganda yang menandakan pergantian tahapan dalam ritual ini.

Perubahan lain juga dapat dilihat pada tahap kabhansule (perubahan posisi) dan tari linda yaitu kebiasaan yang dilakukan oleh pomantoto dan perempuan yang dipingit. Pada tahap kabhasule, ada proses yang harus dilakukan yaitu proses perpindahan dari alam "misal" ke alam "aj"san" yang mengawali proses tersebut dengan mengelilingkan lampu padjamara pada perempuan yang dipingit sebagai tanda penerangan bagi kehidupannya. Penggunaan lampu padjamara hampir tidak digunakan lagi. Hal ini secara tidak langsung mengurangi nilai dan fungsi yang terkandung dalam ritual ini.

Pada tahapan perubahan posisi juga tidak berurutan sesuai dengan kesepakatan yang telah dilaksanakan secara turun-temurun berdasarkan golongan melainkan saat ini berdasarkan pada siapa yang mempunyai acara dan lebih tinggi tingkat pendidikan dan perekonomiannya. Sedangkan pada bagian tari linda, pelaksanaanya hanya diringi dengan alunan ganda, lagu La Kadandio tidak lagi dikumandangkan. Hal ini tidak sesuai dengan ketentuan adat yang mengharuskan dan menjadi syarat pelaksaan tari linda yaitu harus diiringi dengan syair lagu La Kadandio. Syair lagi ini dianggap keramat bagi masyarakat dan hanya dapat dinyanyikan ketika ada tari linda.

Secara umum perubahan dalam suatu ritual tidak dapat dihindari mengingat ritual Kaghombo tumbuh dan berkembang dalam kehidupan masyarakat. Meskipun hal ini terjadi, ritual Kaghombo akan tetap tumbuh dan berkembang dalam masyarakat Muna selama pelaku atau penutur ritual Kaghombo maupun masyarakat pendukung ritual tetap ada. Perubahan dalam ritual ini juga dapat dilihat dari beberapa unsur di dalam proses pelaksanaannya. Misalnya, proses penciptaan ritual kaghombo, waktu pelaksanaan, tempat pertunjukan dan tahap pelaksanaan

\section{A. PROSES PENCIPTAAN RITUAL KAGHOMBO}

Setiap daerah memiliki ritual yang mengandung nilai-nilai luhur yang berfungsi sebagai penyatu dalam suatu komunitas. Nilai-nilai luhur sebagai gambaran hubungan dalam masyarakat, baik hubungan masyarakat dengan Tuhan, maupun hubungan manusia dengan alam atau lingkungannya. Untuk itu, sebuah ritual tidak dapat dipisahkan dari komunitasnya. Pola pemikiran masyarakat seringkali diketahui dari sebuah ritual Kaghombo yang didapat secara turun-temurun. Ritual juga memuat gambaran segala aktivitas masyarakat baik yang telah dilalui maupun yang 
akan datang. Dengan adanya komunikasi sebagai kata kunci sehingga memungkinkan ritual Kaghombo dapat tercipta kembali.

Dalam proses pewarisan terdapat interaksi yang dibentuk oleh penutur atau penyaji ritual Kaghombo masyarakat Muna ataupun penonton. Interaksi yang terjadi diwariskan secara turun temurun yang saling berhubungan satu sama lainnya. Proses pewarisan tersebut merupakan dua hal pokok yang berhubungan dengan proses penciptaan ritual Kaghombo.

Kaghombo merupakan salah satu ritual daur hidup masyarakat Muna yang bernuansa ritual. Ritual Kaghombo ini menjadi puncak kangkilo bagi anak perempuan yang telah memasuki usia remaja dan siap berumah tangga. Artinya, ritual Kaghombo ini sebagai proses pematangan terakhir bagi perempuan sebelum pernikahan atau mencapai kematangan sempurna dalam kehidupannya yang akan datang. Kematangan sempurna yang akan didapatkan bukan hanya berdasarkan kepatuhan terhadap orang tua, menghargai orang lain, namun yang menjadi dasar pijakan tertinggi bagi masyarakat Muna adalah ajaran agama yang didapatkan oleh anak perempuan agar menjadi manusia sempurna. Anak perempuan pada masyarakat Muna memiliki tempat yang istimewa. Oleh karena itu, kalambe wuna diharapkan dapat menjaga pola tingkah laku dalam kehidupan sehari-hari yang tetap bernuansa agama dan kepercayaan yang dimilikinya.

Secara turun-temurun ritual Kaghombo ini terus dilakukan oleh masyarakat Muna sebagai pelunasan tanggung jawab orang tua terhadap anaknya. Proses penciptaan ritual Kaghombo khususnya pada bhatata yang disampaikan pomantoto banyak dipengaruhi oleh peristiwa yang terjadi pada masyarakat. Pomantoto sebagai penyaji dalam ritual Kaghombo memberikan bhatata berdasarkan apa yang terjadi pada masyarakat saat ini. Misalnya pada bhatata berikut ini:

"Doko Kaghombo ini maanano mina napohala bhe dosikola, taaka kafoinaghu welo Kaghombo ini nopohala bhe dosikola, taaka kafoinaghu welo Kaghombo ini nopohala bhe kafoinaghu we sikola".

Kaghombo ini maksudnya, tidak ada perbedaan dengan menuntut ilmu di sekolah, tetapi pesan yang disampaikan dalam ritual Kaghombo ini berbeda dengan ilmu yang didapatkan di sekolah. Penekanan dan nasehat yang diberikan dalam ritual ini sangat berbeda dengan pelajaran menuntut ilmu atau waktu sekolah.

"DokoKaghombo ini maanano dofosentuwu nepandehao, kafoinaghu kamponano ini maighono nekamokulaghi. Moraetua, sigaa lagi ane dhohala finda maitu, okamokula lagi sigaa dopogau daani, eh... mina nasentuwu tuturano anahi amaitu. Sewobha, raawobha ini taaka maanano nendalo".

Pengertian ini maksudnya menyempurnakan apa yang belum diketahui atau ilmu yang belum diketahui. Selama ini yang diajarkan adalah dari orang tua, kapan atau apa bila salah gerak atau bertingkah laku karena yang tidak benar orang tua biasa mengucapkan atau berbicara dengan mengatakan bahwa anak ini tidak sempurna adat pinggitan, sehingga sangatlah penting pengetahuan atau ajaran yang diajarkan pengetahuan Kaghombo itu.

"Sigaa lagi maitu okamokula dopoghau " nalumaintobhe anahi amaitu " dopogau damaitu rampano oanahi lagi maitu doworae mina naepandehao ghuluha. Daanomo siga mahingka 
mie kolalohino, sigaa dua mahingga kamokula dohala finda dua. Dadi itu tabea damehumehulaie kafoinaghu kamponano ini”.

Sebagian atau biasa orang tua berkata bahwa anak ini tidak akan panjang umurnya, berkata demikian karena anak itu dinilai tidak mempunyai kelakuan yang baik atau tingkah laku yang tidak baik dan ini biasanya bukan saja anak kecil tetapi, bahkan orang tua pun salah tingkah atau tidak sopan. Oleh karena itu harus senantiasa diingat-ingatkan yang di ajarkan selama ini.

Bhatata ini diciptakan sesuai dengan kejadian atau kenyataan yang terjadi dalam lingkup kehidupan sehari-hari kalambe wuna. Seorang pomantoto berusaha menyampaikan pesan dengan menyentuh perasaan anak perempuan melalui ungkapan-ungkapan yang lembut, namun memiliki makna yang berhubungan dengan kehidupannya kelak dan sebagai prempuan yang dimuliakan kedudukannya di masyarakat. Anak perempuan dituntut mampu menjaga harga diri keluarga dengan cara bertingkah laku yang baik sesuai ajaran agama dan moral yang diperolehnya. Menurut sebagaian masyarakat Muna yang telah menjalani ritual ini secara turun temurun, bhatata yang disampaikan pada anak perempuan akan membawa perubahan yang baik bagi kehidupannya.

\section{B. Waktu Pelaksanaan Ritual}

Ketentuan waktu dalam ritual ini berdasarkan kepakatan yang telah diwarisi secara turun temurun. Pertama kali ritual dilaksanakan selama 40 hari 40 malam sesuai dengan keputusan Raja Muna XVI La Ode Huseini sebagai proses penciptaan manusia yang melewati empat alam yakni (1) alam arwah yaitu roh masuk bersifat rahasia Tuhan; (2) alam misal yaitu roh sudah berada di sekitar manusia lainnya dalam kandungan; (3) alam aj"sam yaitu roh sudah dititipkan kepada manusia sehingga manusia lahir dari kandungan; (4) alam insani yaitu manusia telah lahir dan berada di bumi. Penentuan waktu ini juga disesuaikan dengan golongan strata sosial keluarga kalambe wuna. Golongan kaomu dipandang sebagai golongan bangsawan yang pasti memiliki kemampuan lebih dibandingkan golongan maradika dan walaka.

Seiring dengan perkembangan waktu, pelaksanaan ritual Kaghombo dikurangi menjadi empat hari empat malam. Kaum perempuan mendapat berbagai pengetahuan tentang tata cara kehidupan baik hubungannya dengan Tuhan maupun hubungannya dengan sesama manusia. Empat hari empat malam mengandung makna sebagai berikut:

empat hari empat malam, artinya bahwa raga manusia terdiri atas empat bagian yang saling berekerja sama dalam segala aktvitas manusia setiap saat. Misalnya, kepala sebagai pusat pemikiran manusia yang menjadi sumber pengambilan keputusan yang akan diwujudkan dalam bentuk tindakan, dada dalam hal ini merupakan pusat keteguhan batin yang menjadi sumber keyakinan manusia yang paling utama terhadap Allah SWT, sebagai pencipta alam semesta beserta isinya baik yang lahir maupun gaib, perut yang merupakan asal datangnya segala nafsu manusia baik nafsu yang diridhoi maupun yang dilarangNya. Kemudian tangan dan kaki hal ini merupakan pelaksana utama daripada realisasi hasil, kerjasama keempat bagian tersebut yang diwujudkan dalam bentuk tindakan yang sangat konkrit. Pemberian makan pada kalambe wuna yang dibatasi artinya bahwa dalam kehidupan duniawi tidak serba cukup dengan keinginan, manusia hanya mampu berusaha, tetapi tuhan yang menentukan segalanya. Pakaian dan perhiasan yang beraneka ragam warna artinya bahwa kehidupan masyarakat terdiri atas berbagai macam tipe manusia, dan 
alangkah baiknya kalau bersatu agar terbentuk kerjasama yang baik untuk memudahkan pada pencapaian tujuan yang diinginkan. Penggunaan pakaian dan perhiasan disesuaikan dengan adat pernikahan kalambe wuna. Pencoretan tanah artinya seorang gadis menyadari diri bahwa keberadaan dirinya di muka bumi ini bersifat sementara yang nantinya akan kembali pada tanah. Penerapungan bunga pinang artinya gadis tersebut membuang sifat-sifat jeleknya. (Wawancara dengan Waode Musa, 06 September 2016).

Selain empat hari empat malam waktu pelaksanaan ritual ini juga dapat dilakukan selama dua hari dua malam dan sehari semalam. Pengurangan waktu pelaksanaan ini biasanya disebabkan oleh karena sebagian besar kalambe wuna saat ini tidak mampu untuk menjalani ritual ini selama empat hari empat malam dan kesibukan masyarakat pendukung ritual itu sendiri sehingga waktu pelaksanaan disesuaikan dengan jadwal pekerjaan mereka. Penentuan waktu pelaksaan ritual ini juga dipengaruhi oleh faktor ekonomi masyarakat pendukung ritual. Jika masyarakat yang mengadakan ritual Kaghombo memiliki keuangan yang cukup, biasanya waktu pelaksanaa selama empat hari empat malam. Sebaliknya jika perekonomian kurang, biasanya anak perempuan mereka akan dititipkan kepada keluarga lain atau pelaksanaan Kaghombo hanya dilakukan sehari semalam. Namun sebagian masyarakat saat ini yang memiliki tingkat pendidikan, kepercayaan agama dan perekonomian yang lebih, biasanya tidak lagi melaksanakan tahapan-tahapan dalam ritual ini.

"Mereka hanya meminta pada tokoh agama dan pomantoto untuk membuatkan oe metaano (air baik) dan oe modaino (air buruk), lalu dimandikan kepada anak perempuan. Mereka beranggapan bahwa seorang anak perempuan tidak mesti melakukan tahapantahapan dalam ritual ini, karena bisa saja berakibat yang tidak baik. Misalnya. tidak mandi selama berhari-hari, memakai bedak seluruh badan dan jatah makan yang dibatasi. Menurut mereka perlakuan seperti ini tidak serta merta akan mengubah sikap anak perempuan dalam kehidupannya kelak (wawancara dengan La Mutiara, 30 September 2016).

Tempat pertunjukan ritual Kaghombo sangat diperhatikan oleh masyarakat pemilik ritual. Hal ini dilakukan karena posisi kalambe wuna dalam ritual ini sangat dimuliakan yakni sebagai perempuan suci dan diibaratkan akan terlahir kembali dari perut ibunya. Untuk itu, tempat proses pelaksanaan ritual yang meliputi kafoluku, kabansule, kalempangi, dan kafosampu dibuat secara khusus yang menyerupai kotak persegi empat yang di dalamnya tidak terdapat cahaya. Sedangkan tahap akhir pelaksanaan ritual ini yang meliputi katandano wite, tari linda, kahapui dan kaghorono bhansa juga dibuat secara khusus (panggung) di ruang terbuka yang dapat dilihat secara langsung oleh masyarakat pendukungnya.

Namun, seiring dengan perkembangan zaman sebagian masyarakaat tidak lagi menjalankan aturanaturan yang telah disepakati secara turun-temurun.

"kotak persegi empat atau yang dikenal masyarakat Muna dengan sebutan songi sudah jarang digunakan lagi, sebagian masyarakat pendukung ritual ini mengganti dengan kamar yang berada dalam rumah dan tahapan lainnya seperti katandano wite, tari linda, tidak dilakukan di atas panggung. Perlakuan ini secara tidak langsung mengurangi nilai dan fungsi yang terkandung dalam ritual ini (wawancara dengan Wandoapa 56 tahun Jumat 10 September 2016)". 
Pembuatan panggung itu sendiri berfungsi sebagai tanda bahwa seorang perempuan Muna memiliki kedudukan yang terhormat dalam masyarakat Muna. Untuk itu, posisinya dibuat lebih tinggi dibandingkan masyarakat lain yang menyaksikan ritual Kaghombo ini.

Penyaji ritual dalam ritual ini sebagian besar dilakukan oleh imam perempuan (pomantoto) sedangkan imam laki-laki (lebe) hanya pada tahapan awal dan akhir ritual ini. Penentuan ini memang sudah disepakati secara turun-temurun. Hal ini dikarenakan pelaku utama dalam ritual Kaghombo ini adalah perempuan yang sedang mensucikan diri.

Menurut wawancara dengan La ghanta (65 tahun pada 29 September 2016) ritual Kaghombo adalah ritual yang harus dilaksanakan perempuan dewasa dan sudah menjadi kewajiban orang tua untuk melaksanakannya sekali seumur hidup dengan maksud menuntun anak ke jalan yang benar serta mensucikan diri dan jiwa anak agar dalam hidupnya tidak tersesat dengan gangguan-gangguan roh jahat yang menjerumuskan hidup manusia dalam kemungkaran dan keniscayaan.

Dari definisi yang dikemukakan di atas, dapat disimpulkan bahwa ritual Kaghombo merupakan ritual yang dilaksanakan sekali seumur hidup bagi perempuan yang telah masuk usia dewasa sebagai proses penyucian diri, agar lebih bertanggung jawab dan siap menghadapi kehidupan yang akan datang.

Ritual ini juga syarat dan permainan rakyat dengan musik yang mengiringi segala hal yang berkaitan dengan tahapan pelaksanaannya. Permainan rakyat biasanya dimainkan oleh laki-laki yang akan diringi dengan alunan ganda. Alunan ganda ini akan selalu terdengar setiap pergantian tahapan pelaksanaan Kaghombo.

Selain itu, kaum laki-laki dalam ritual ini juga bertugas untuk menggendong kalambe wuna ketika keluar dari dalam Kaghombo. Laki-laki yang bertugas ini hanya diperbolehkan bagi seseorang yang mempunyai hubungan keluarga yaitu ayah, kakak laki-laki, paman, sepupu laki-laki atau calon suami dari perempuan yang dipingit. Dalam ritual ini juga disepakati bahwa kaum lakilaki hanya diperbolehkan berada di luar songi untuk menjaga pelaksanaan ritual.

Dalam ritual Kaghombo penggunaan kostum sangat diperhatikan dan disesuaikan dengan ketentuan adat dari seorang kalambe wuna yang akan di Kaghombo. Pengaturan dalam pakaian adat ini telah berlangsung sejak zaman pemerintahan Titakono dan bhonto bhalano La Marati (Couvreur, 2001: 40-52). Pakaian ini diatur sesuai dengan ketentuan masing-masing golongan. Misalnya, golongan perempuan kaoumu yang belum menikah memakai satu lembar sarung, satu kain sebatas mata kaki, kain kedua dipakai di atasnya, tetapi hanya sebatas sedikit di atas lutut.

Golongan walaka memakai tiga lembar sarung dan memakai kabhantapi yang diletakkan di bahu sebelah kanan. Sedangkan dua golongan lainnya yaitu anangkolaki dan maradika memakai tiga kain, yang berbeda hanya penempatan kain kedua yang berada di dibawah betis dan sebatas mata kaki. Penggunaan perhiasan juga disesuaikan pada golongan-golongannya dan status kalambe wuna yang sudah menikah maupun yang belum menikah.

Kebiasaan cara berpakaian yang lain dilakukan oleh kalambe wuna yang belum menikah di zaman dahulu yakni menggunakan kain dengan cara mengikatnya pada salah satu bahu dan mengikatnya di atas dada. Dalam tahapan pelaksanaan ritual Kaghombo juga diperlihatkan penggunaan kain atau sarung yang diikatkan di atas dada. Pada tahapan kafoluku, kabhansule, dan kalempangi menggunakan kain putih dan sarung yang diikat pada bagian atas dada. Kain putih yang digunakan memiliki makna yang berhubungan dengan penggambaran kesucian diri seorang 
perempuan. Namun, sebagian pelaku dalam ritual ini tidak lagi memperhatikan nilai yang terkandung dalam pemakaian kain putih.

Pergeseran nilai mulai terjadi dalam ritual ini, beberapa unsur yang menunjang di dalamnya mulai dihilangkan. Pada tahapan kafoluku perempuan yang akan di Kaghombo tidak lagi menggunakan kain putih yang telah menjadi kesepakatan dalam ritual ini yang telah diwariskan secara turun temurun.

Selain penggunaan kain atau sarung dalam ritual ini, mengenai perhiasan dan pendandanan bagi kalambe wuna pada masa sekarang, sebagian kebiasaan yang telah dilakukan secara turuntemurun mulai dihilangkan oleh para pelaku ritual ini. Misalnya, saat proses kabhindu yaitu pembersihan bulu-bulu halus di wajah dan pembuatan poni yang harus dilakukan sebagai tanda pembeda dengan peserta Kaghombo lainnya yang lebih dahulu menikah.

“....keluarga yang menyelenggarakan ritual Kaghombo ini biasanya, dilakukan ketika ada anak perempuannya yang akan menikah setelah empa hari empat malam melewati Kaghombo. Untuk membedakan perempuan Muna mana yang akan menikah setelah Kaghombo berlangsung dengan mana yang tidak akan menikah terlihat pada potongan rambut (poni) akan berbeda bentuknya dengan yang sudah menikah...". (wawancara dengan Wandoapa, 10 September 2016),

\section{Perlengkapan Ritual Kaghombo}

Perlengkapan ritual Kaghombo meliputi bahan dan alat dalam tahapan proses pelaksanaannya. Bahan dan alat dalam kaeghomboha (Kaghombo) ini terdiri dari: (1) Bhansano ghai dan bhansano bea, digunakan sebagai pengalas kepala bagi kalambe wuna dalam Kaghombo. Saat ini penggunaan pengalas kepala biasanya hanya memilih salah satu dari dua pengalas kepala. Pemilihan salah satu pengalas kepala tidak sesuai dengan ketentuan adat yang seharusnya digunakan kedua-duanya, (2) Padjamara, (lampu ritualonal masyarakat Muna) yang tidak dinyalakan; (3) Dua buah palangga (tempat yang terbuat dari lidi pohon aren dalam bentuk anyaman). Palangga merupakan analogi dari kendaraan Tandiabe pada awal memasuki daerah Muna. Pangga yang berisikan beras, telur dan uang perak. Saat ini sebagian besar masyarakat Muna tidak lagi menggunakan palangga, namun masyarakat menggantinya dengan wadah yang terbuat dari plastik; (4) Polulu (kampak) dan kandole (bambu alat tenun) memiliki makna sebagai isyarat bahwa siap mengahadapi kehidupan rumah tangga yang penuh tantangan. Kedua benda ini dimasukkan dalam ruang Kaghombo sebagai simbol bahwa kalambe wuna diharapakan mampu menghadapi seluk beluk kehidupan. Namun kenyataannya, penggunaan kandole sudah jarang ditemukan dalam ritual Kaghombo.

(5) Jagung dan umbi-umbian (ghofa dan mafu), memiliki makna kehidupan; (6) Kapas dan benang sebagai bahan sarung yang memiliki makna keterampilan seorang perempuan bahwa mampu menghadapi keluarga apabila telah mampu membuat tenunan (ukuran zaman dahulu): (7) Anyaman daun kelapa yang masih muda (bhale) yang berbentuk segi empat ukuran 50x50 cm yang jumlahnya disamakan dengan jumlah kalambe wuna yang dipingit; (8) Tikar yang terbuat dari daun agel (ponda bhale), tikar ini digunakan sebagai alas tempat tidur para kalambe wuna. Menurut kepercayaan masyarakat Muna, tikar tersebut tidak dapat diganti dengan karpet atau tikar plastik, karena memiliki nilai filosofi kehidupan yaitu sebagai perempamaan dalam kehidupan keluarga tidak hanya mengaharapkan yang enak tetapi juga harus siap menghadapi penderitaan dalam kehidupan; (9) Kain putih sebagai alas tikar ponda bhale yang memiliki makna kesucian; (10) 
Obura (bedak); (11) Sultaru adalah miniatur yang mendampingi atau berada di belakang perempuan yang dipingit, ketika melaksanakan tahapan katandano wite, tari linda.

Kenyataan yang terjadi sekarang dalam pelaksanaan ritual ini, sebagian pelengkapan ritual ini mulai tidak diperhatikan nilai dan fungsinya. Misalnya, kapas dan benang sebagai bahan sarung yang memiliki makna keterampilan seorang perempuan: mampu menghadapi keluarga apabila telah bisa membuat tenunan (ukuran zaman dahulu) tidak lagi dimasukkan ke tempat Kaghombo yang bermakna kelak bila menghadapi kehidupan sulit, perempuan mampu berusaha, membantu keluarganya.

Begitu juga dengan jagung dan umbi-umbian (ghofa dan mafu), sudah jarang dimasukkan ke tempat Kaghombo. Saat ini jagung dan umbi-umbian diganti dengan beras, telur dan ketupat. Hanya saja pelengkapan yang ini masih memiliki makna yang sama: penunjang dalam kehidupan nantinya.

Sementara itu, penonton menjadi salah satu bagian yang harus diperhatikan dalam pertunjukan ritual Kaghombo. Hal ini sesuai dengan pendapat Finnegan yang membagi audiens menjadi pendengar dan penonton, serta audiens yang ikut serta dalam penceritaan, terpisah dari penceritaan (Tuloli, 1991:225). Penonton berperan sebagai pemberi respon atas keberhasilan atau kegagalan sebuah ritual. Tanggapan penonton yang diperlihatkan akan beragam sesuai rangsangan yang diberikan oleh pelaku ritual. Sweeny (1987: 2) mengemukakan, pelaku ritual secara sengaja merangsang audiens agar memberikan reaksi tertentu pada sebuah pertunjukan. Ketika suatu pertunjukan ritual berakhir, maka kesan yang akan ditimbulkan bisa sama atupun akan berbeda.

Dalam ritual Kaghombo terutama pada pertunjukan permainan rakyat, pada tari linda dan tahap akhir yaitu kaghorono bhansa dapat dilihat reaksi yang beragam. Penonton dalam ritual ini tidak dibatasi pada pembagian golongan dan usia namun dapat disaksikan seluruh masyarakat. Masyarakat pada umumnya berdatangan ketika mendengar aluna ganda yang dimainkan oleh orang-orang yang memiliki kemampuan sehingga dapat menarik perhatian masyarakat lainnya.

Ritual ini juga dapat membawa jodoh bagi kalambe wuna yang di Kaghombo. Kertertarikan dapat terjadi ketika seorang penonton terbuai dengan kelemahlembutan kalambe wuna saat menari linda dan pada umumnya perempuan yang telah di Kaghombo memiliki aura kedewasaan dan kecantikan alami. Adapun berbagai reaksi yang dikeluarkan oleh penonto sangat beragam.

Reaksi yang diberikan umumnya berbeda-beda. Tuloli (1991:259), memberikan tiga alasan mengenai timbulnya reaksi pada sebuah penampilan yaitu (1) isi dan suasana adegan yang menyentuh perasaan pendengar; (2) pemakaian kata-kata atau ungkapan tertentu; (3) gaya tambahan sebagai hiasan pada setiap adegan, baik yang berhubungan dengan alat musik, suara, maupun gerakgerik penutur. Sebuah pertunjukan tentu saja menimbulkan reaksi dari berbagai individu maupun kelompok masyarakat yang menyaksikannya. Reaksi yang didapatkan tentu saja akan berbeda antara individual dan kelompok.

Pelaksanaan ritual Kaghombo pada masyarakat Muna juga menimbulkan reaksi bagi masyarakat pendukungnya maupun masyarakat di luar pendukungnya. Dari awal tahap pelaksanaan ritual ini ditandai dengan pemukulan ganda, yang kemudian terus mengiringi pelaksanaannya. Pemukulan ganda yang selalu menyertai setiap tahapan dalam ritual ini memiliki tujuan tersendiri yakni sebagai pemberitahuan pada masyarakat pendukung ritual atau masyarakat umum lainnya.

Kesan yang ditimbulkan akan beragam dan dapat terjadi pada siapapun. Misalnya, anakanak dengan polos akan tersenyum dan bahkan tertawa sedangkan orang dewasa dengan hikmat menyaksikan tari linda yang diiringi dengan alunan ganda yang musiknya berirama cepat 
sedangkan penarinya akan bergerak lemah gemulai. Reaksi lain yang biasa juga terjadi saat tari linda yaitu pihak keluarga atau penonton lainnya akan bersorak ramai ketika seorang pemuda dengan sigap memberikan sebuah cincin pada kalambe wuna yang sedang menari. Peristiwa ini biasa dianggap sebagai bukti kesungguhan dari pemuda tersebut untuk secepatnya melamar sang gadis. Akan tetapi, sebagian dari penonton yang umumnya berasal dari suku lain justru tidak bereaksi. Hal ini bisa terjadi pada sebuah pertunjukan, karena penonton tidak mengerti bahasa daerah yang digunakan dan tidak mengetahui makna dari gerakan-gerakan atau bunyi-bunyian yang dipertontonkan.

\section{PEMBAHASAN}

Mind (pemikiran), dipertegas oleh (Mulyana: 2001:70) adalah kemampuan untuk menggunakan simbol dan makna sosial yang sama dimana setiap individu mengembangkan pikiran mereka melalui interaksi dengan individu lain. Dalam kaitannya dengan ritual Kaghombo, ritual merupakan salah satu bagian dari siklus kehidupan manusia. Ritual merupakan sarana yang menghubungkan manusia dengan hal-hal yang dianggap sakral. Ritual dipahami sebagai bentuk penyelenggara hubungan antara manusia dengan yang gaib, hubungan manusia dengan sesamanya.

Self, diri pribadi, (Mulyana: 2001:70) merupakan kemampuan untuk merefleksikan diri setiap individu dari penilaian sudut pandang atau pendapat orang lain dari teori interaksionisme simbolis. Dalam kaitannya dengan ritual kaghombo, ritual Kaghombo menjadi simbol proses terciptanya manusia dari setetes darah hingga menjadi manusia sempurna. Kemudian berhubungan dengan masa peralihan yakni masa peralihan perempuan remaja ke usia yang lebih dewasa atau masa peralihan kejenjang perkawinan.

Society, masyarakat, (Mulyana: 2001:70) merupakan hubungan sosial yang diciptakan, dibangun, dan dikonstruksikan oleh setiap individu di tengah masyarakat dan setiap individu terlibat dalam perilaku yang mereka pilih secara aktif dan suka rela. Dalam kaitannya dengan ritual kaghombo, ritual Kaghombo selalu dilaksanakan oleh masyarakat Muna, baik yang berada di luar wilayah Kabupaten Muna sebagai induk dari masyarakat Muna maupun yang berada di luar wilayah Kabupaten Muna. Masyarakat Muna yang menetap di daerah lain tidak serta merta meninggalkan ritual Kaghombo yang telah diwariskan secara turun temurun, walau pun sebagian tahapan pelaksanaan tidak dilakukan dengan sempurna.

\section{KESIMPULAN}

Kesimpulan penelitian ini adalah: Ritual Kaghombo merupakan salah satu ritual masyarakat Muna yang dilaksanakan sebagai puncak kangkilo (sunatan) dari anak perempuan, dan memiliki nilai-nilai luhur yang dapat diterapkan dalam kehidupan sehari-hari masyarakat Muna khususnya Desa Mabolu. Nilai-nilai dalam ritual ini sangat penting bagi kehidupan masyarakat muna karena memuat aspek sosial, religius, filosofis dan kesejarahan.

Perubahan ritual Kaghombo dari zaman ke zaman, menjadi tidak lazim lagi bagi Masyarakat Muna Desa Mabolu. Perubahan ritual Kaghombo dalam perkembangannya dipengaruhi oleh perubahan masyarakat pendukungnya. Perubahan ini dipengaruhi oleh berbagai aspek yakni internal dan eksternal. Faktor internal meliputi kepercayaan, agama, dan perkembangan pendidikan. Sedangkan faktor eksternal yang berasal dari luar masyarakat pendukungnya misalnya aspek ekonomi. 
Pemikiran masyarakat Desa Mabolu khususnya kalambe wuna (gadis yang dipingit) mulai terpengaruh dengan hal-hal baru yang didapat dari pendidikan modern. Pemikiran ini menganggap ritual ini pada beberapa bagian bertentangan dengan pemikiran modern. Misalnya, ritual dilakukan sebagai proses pematangan dan pensucian diri dalam menghadapi kehidupan berumah tangga. Hal ini bertolak belakang dengan pemikiran mereka yang berpendidikan tinggi dengan pendapat seorang perempuan berpendidikan tinggi mampu berpikir dengan baik dan memiliki pekerjaan.

\section{Daftar Pustaka}

Abdurrauf Tarimana, 1994. Kebudyaan Tolaki. Jakarta: Balai Pustaka

Barker, Chris. 1980. Cultural Studies : Teori dan Praktik, Terjemahan. Tim Kunci Cultural Studies Depdikbud, 1997. Kamus Besar Bahasa Indonesia. Jakarta: Balai Pustaka.

Efendi, Uchayana Onong. 1996. Kamus Komunikasi. Jakarta: CV. Mandar Maju.

Efendi, Uchayana Onong. 1986. Teori dan Filsafat Komunikasi. Bandung: Rosda Karya.

Liliweri, Allo. 1994. Gatra-Gatra Komunikasi Antar Budaya. Yogyakarta: Pustaka Pelajar.

Liliweri, Allo. 2004. Dasar-Dasar Komunikasi Antarbudaya. Yogyakarta: Pustaka Pelajar.

Litle John. 1995. Komunikasi Antar Persona (Terjemahan). Makassar: Unhas.

Mulyana, Dedy. 2011. Ilmu Komunkasi Suatu Pengantar. Bandung: Citra Aditya Bakti

Pratikto, Priyono. 1989. Manusia Kebudayaan dan Lingkungan. Bandung: Citra Aditya Bakti.

Soekanto, Soejono. 1985. Pengantar Sosiologi dan Perubahan Sosial. Jakarta: Bina Cipta.

Wirjono, Projodikoro. 1991. Hukum Perkawinan di Indonesia. Bandung: Sumber

Wisngodipoero, Soeroyo, 1984. Pengantar dan Azas-Azas Hukum Adat. Jakarta: Gunung Agung 